\title{
The Growth Of Cause Marketing: Past, Current, And Future Trends
}

\author{
Susan Rozensher, Iona College, USA
}

\begin{abstract}
When American Express launched a campaign in 1984, pledging to donate a penny to the Statue of Liberty restoration project for each cardmember transaction, the promise of cause marketing caught the attention of both nonprofits with fundraising needs, as well as marketers seeking to enhance corporate image while maximizing sales and profits. Since that time, cause marketing (also known as cause-related marketing, cause-brand partnerships, or cause tie-ins) has been the subject of continuing debate and change, while growing in importance and prevalence. The current paper provides an examination of the debate as it has evolved, of the methods and strategies that have been popularized and criticized, and of the outlook for the future of cause marketing. All of these topics will be considered from the varying perspectives of the parties involved in cause marketing: the consumer, the corporation, and the nonprofit organization. In particular, the implications of some newly identified developments will be discussed, together with an assessment of specific opportunities and obstacles that lie ahead.
\end{abstract}

Keywords: Cause Marketing; Cause-related Marketing; Cause Tie-ins; Cause-brand Partnerships

\section{INTRODUCTION}

hen American Express launched an innovative marketing campaign in 1984, promising to donate a
penny to the Statue of Liberty restoration project for each cardholder transaction, and a dollar for each new credit card, over a million dollars was quickly raised and cardholder transaction activity was boosted by an astounding $28 \%$. This innovative alliance between a corporation and a nonprofit put cause marketing firmly on the map. No doubt the promise of cause-related marketing caught the attention of both nonprofits with fundraising needs, as well as marketers seeking to enhance corporate image while maximizing sales and profits. Since that time, cause-related marketing (also referred to more recently as cause marketing) has been the subject of continuing debate and change, all the while growing in importance and prevalence. The current paper provides an examination of the debate as it has evolved, of the methods and strategies that have been popularized and criticized, and of the outlook for the future of cause marketing.

The partnerships between companies and causes, pairing the purchase of a product with the support of a charity, have sometimes been called cause-related marketing sponsorships, or alternately, cause tie-ins, cause-brand partnerships, or company-cause linkages. They are designed to create a relationship between a brand and a cause that is used to market a product. Often, the partnership is a long-term one. In an important early article on the subject of this practice published in 1988 (Varadarajan \& Menon), the arrangement was referred to as a "coalignment of marketing strategy and corporate philanthropy".

Since the landmark American Express cause-marketing campaign, there have been many campaigns that received a great deal of consumer attention and monetary support. Examples include the Product Red campaign, spearheaded by rock star Bono; Nike and the Girl Effect campaign, which focuses on improving the plight of poor adolescent girls in developing regions of the world; General Mills' long-running Boxtops for Education; Susan G. Komen for the Cure, with links to numerous companies; and Tide's "Loads of Hope", with mobile Laundromats sent to New Orleans after Katrina and to other disaster areas since then. 


\section{RESEARCH}

This paper reviews both academic and industry literature regarding cause-marketing in an effort to examine the evolving attitudes towards the practice, as well as its impact on consumers, companies and the causes with which they have partnered. In the world of marketing, the concept of cause-related marketing was initially viewed by some as a valuable new marketing tool with great promise (Varadarajan \& Menon, 1988). The idea of "doing well by doing good" seemed like a win-win-win situation - the corporation burnishes its reputation as a socially responsible entity while maximizing profits and differentiating itself; the cause receives needed funds as well as the attention and involvement of the public in support of its mission; and consumers acquire a product, feel good about the transaction, and are pleased they have made a donation to a cause without sacrificing any money. However, many questions were raised at the time that cause-marketing was still in its infancy. Why, for instance, should corporations' reputations benefit from the halo effect of being associated with a nonprofit organization and its cause, when the partnership was designed to help the bottom line of corporations? Could this alliance represent a corporation's exploitation of a tragic situation? A serious risk was also perceived for the nonprofits, which could end up sullying their own reputations through this partnership. Consumers might reject the relationship, and the parties in it, as deceptive and untrustworthy.

More recently, a number of potential disadvantages have been pointed out by Eikenberry (2009). She has argued that cause-marketing (which she dubbed "consumption philanthropy") has a corrupting effect. Specifically, it encourages consumers to give only if they get something in return and to think that, through consumption, they can change the world. It thereby steers people away from taking action to better the world and also makes them less likely to donate outright. At the same time, Eikenberry maintains, corporations will expect to derive more benefit and have more control over the money that they donate (as opposed to donating to nonprofits with no strings attached and for unrestricted use, as practiced in more traditional corporate philanthropy). Further, causes that are not popular with the general public will lose support.

Despite the debates surrounding cause-marketing, the practice has grown enormously since its start in 1984, with growing consumer support for these arrangements. In 1993, an industry survey (Cone) found that $66 \%$ of consumers supported the practice; in 2004, the Cone industry survey (DaSilva) found that $72 \%$ supported the practice. In 2010 (Cone), American consumers showed no sign of tiring of these connections despite the ubiquity of cause-marketing; indeed, an impressive $88 \%$ of consumers supported the practice and $83 \%$ said they want more of the products, services, and retailers that they use to partner with causes. The results of another recent industry survey in 2010 concurred (PR Week/Barkley).

\section{Benefits for the Nonprofits/Causes}

With the consistently growing and now very widespread approval of consumers, the promise of causemarketing seems yet to be realized. For the charities involved, cause-marketing offers a number of benefits. Specifically, not only are funds raised for the cause, but also public awareness, as well as public interest and involvement in the cause, are increased.

The issue of trust, however, has emerged as central to the potential for impact. Specifically, $78 \%$ of consumers reported that a partnership between a nonprofit and a company that they trust makes a cause stand out (2010, Cone Nonprofit Marketing Trend Tracker). Consumers reported other favorable feelings and behaviors towards nonprofits that partner with a company that they trust; namely, that they are more likely to feel positively toward the nonprofit (56\%), more likely to donate to the nonprofit (50\%), and more likely to volunteer for the nonprofit (41\%). So the benefits to the nonprofits in such an arrangement with a trusted company appear to be quite significant. Very pronounced support was also found in an international survey of 10 of the 11 largest countries by GDP (Cone/Echo, 2011). Seventy-eight percent of respondents either somewhat or strongly agreed with the statement that they would volunteer for a cause that a company they trust supports and $81 \%$ agreed they would donate to a charity supported by a company that they trust. 


\section{Benefits for the Corporations}

From the perspective of the company and its products, the benefits can also be quite extensive and have been documented in several industry studies. Specifically, $74 \%$ of consumers reported that they are more likely to buy products of a particular brand because of its association with a cause (PRWeek/Barkley, 2010); 75\% of those consumers and, similarly, $61 \%$ of respondents in the Cone 2010 survey, said they would try a product (new or unfamiliar to them) because it supported a cause. An impressive $80 \%$ of respondents said they would be more likely to switch to brands that support a cause (Cone, 2010), and $85 \%$ of consumers have a more positive image of a product or company if it's associated with a cause they support (Cone, 2010). Similar findings recently emerged from an international study (Cone/Echo, 2011) which found that $94 \%$ of consumers are either somewhat likely or very likely to switch to a brand associated with a good cause when price and quality are equal. Many other measures demonstrated overwhelming support for companies aligning themselves with causes. For example, a full 93\% agreed somewhat or agreed strongly with the statement that they would buy a product or service associated with a cause and $65 \%$ reported they had done so within the last 12 months.

\section{Demographic Factors}

The trend toward increased use of cause-marketing may be spurred further by the particular support of young consumers for this practice. A full $94 \%$ of millennials (18-24 year-olds), compared to an overall average of $88 \%$, consider cause-marketing to be acceptable, according to an industry survey (Cone, 2010). In addition, 53\% of millennials, compared with $41 \%$ on average, said they have bought a product this year that supported a cause. Support for charitable causes among young consumers, and their inclination to purchase products promoted through cause-marketing, has also been noted in academic studies (Cui, Trent, Sullivan, and Matiru, 2003; Youn and Kim, 2008).

New opportunities for cause-marketing may lie in targeting a demographic that has been somewhat overlooked thus far: namely, men. One of the most interesting results of the recent PRWeek/Barkley survey (2010) was the finding that an overwhelming percentage of men (88\%) believe that it is important for companies to support a cause. Nevertheless, only $68 \%$ of corporate executives reported that they currently have plans to target men with their cause-marketing. Furthermore, $61 \%$ of men reported that they purchased a brand because it supported a cause and 55\% would pay more for a brand that supported a cause. In addition, 67\% indicated they would try a brand because it supported a cause (PRWeek/Barkley, 2010).

Men, though, have not generally been targeted in cause-marketing efforts in the past. It is understandable that women have been considered the prime demographic target of cause-marketing campaigns since, indeed, several studies have found that women have more favorable attitudes than men toward cause marketing (Ross, Patterson, and Stutts, 1992; Ross, Stutts, and Patterson, 1990-91; Moosmayer, Dirk C. and Alexandre Fuljahn, 2010). (It should be noted, however, that a study by Youn and Kim, 2008, did not find such an effect for gender.) Furthermore, in the Cone 2010 survey, mothers were identified as the demographic group most supportive of causemarketing, with $95 \%$ of them reporting that cause marketing is acceptable (vs. $88 \%$ on average). In addition, $92 \%$ said they want to buy products supporting a cause (vs. an average of $81 \%$ ). Not surprisingly, $61 \%$ of mothers reported purchasing cause-related products, much more than the average of $41 \%$. However, despite the gender differences that have been found, men are now clearly receptive to cause-marketing efforts and represent an untapped target market.

Significant opportunity for cause-marketing also lies in the use of social media, which has already been harnessed for that purpose. So-called "Charity Apps" have enabled companies to partner with charities using checkin applications like Foursquare, Gowalla, Loopt, and Facebook Places. When users check-in to stores or businesses (e.g., Hard Rock Café) using an app such as Facebook Places, which broadcasts their location, Hard Rock International donates a dollar to WhyHunger, a charity dedicated to fighting global poverty and hunger. Sometimes the user is given the chance to make a selection from a list of charities (as in Cause-World). In Austin, for example, during a major music and film festival, Microsoft and Paypal together donated 25 cents to Save the Children's Haiti Relief Effort each time someone checked in on Foursquare from any business in Austin. During the 2010 holiday season, The Gap donated a dollar to CampInteractive, a charity, for every customer that checked-in, in addition to 
the $30 \%$ discount for checking in. Businesses and charities set up these partnerships freely and easily - since the apps are open and accessible to users and businesses.

\section{CONCLUSION}

While the future of cause-marketing has a great deal of promise, there are a number of serious issues that may present obstacles or cause setbacks. Many consumers, although receptive to the concept of cause-marketing, are still skeptical about the motives of the companies involved (Kim and Lee, 2009). Indeed, in the PRWeek/Barkley survey (2010), 23\% of consumers said that the primary motive of companies is a tax write-off and another $20 \%$ said it was publicity.

Another factor that may hamper the unbridled growth of cause marketing is that the partnership can, and often does, increase the price of the cause-related products and of other products that the company sells. In fact, only $19 \%$ would be willing to buy a more expensive brand if it supported a cause (Cone, 2010). Consumers are also not sure about how much money actually gets donated, according to Eikenberry (2009). A related study examined consumer confusion about donation amounts expressed either as a percentage of the sales price, a percentage of profits, or in vague terms (e.g., "a portion of the proceeds" will be donated). The results demonstrated that consumers consistently overestimate donation amounts when expressed as a percentage of profits (Olsen et al, 2003).

As consumers become more cause-marketing savvy, they are likely to continue to demand more transparency with regard to the efforts and results of cause marketing campaigns, and with the explosion of social media and its increased use in cause-related marketing, consumer scrutiny of cause marketing campaigns is likely to intensify. Indeed, recent research has detected early signs of a public that is demanding more accountability from companies and causes engaging in cause marketing. Specifically, 40 percent of consumers recently reported they will not purchase a company's products or services if the results of the company's corporate social responsibility efforts are not communicated (2012 Cone Communications Corporate Social Return Trend Tracker). The same report found an overwhelming demand for better communications; that is, $86 \%$ of consumers said they wish companies would tell them more about the results of their corporate social responsibility efforts and $90 \%$ believe companies should tell them more about the results of their efforts rather than just the amount of money they donate or invest.

Similarly, a study of attitudes and intentions during the recent 2012 holiday season points toward a significant drop in enthusiasm for products associated with a cause-marketing campaign. Specifically, the percentage of consumers who said they plan to purchase, or have already purchased, cause-related gifts during the holiday season plummeted from $49 \%$ in 2010 to just $16 \%$ at the same time of year in 2012 (2012 Cone Communications Holiday Trend Tracker). That study also detected a significant skepticism on the part of consumers, of whom $68 \%$ questioned the impact of their cause-related holiday purchases and 75 percent wished that companies would tell them more about the impact of cause-related holiday products. At the same time, 75 percent of consumers said they feel better about companies that support holiday causes and $71 \%$ of consumers expect companies to support causes during the holidays. So while consumers have come to expect companies to support causes, their unquestioning enthusiasm for those efforts has matured into the demand for more transparency, more accountability, more proof of impact, and improved communication from the parties engaging in cause-marketing. These demands show no signs of abating in the near future.

\section{AUTHOR INFORMATION}

Susan Rozensher is Professor of Marketing at Iona College, Hagan School of Business, New Rochelle, New York. She received her Ph.D. from Columbia University and her teaching and research interests include cause marketing, customer loyalty, customer-company identification, marketing research, and marketing education. E-mail: srozensher@iona.edu 


\section{REFERENCES}

1. Cone Cause Evolution Study (2010). Retrieved from http://www.conecomm.com/2010-cone-causeevolution-study

2. Cone Communications Corporate Social Return Trend Tracker (2012). Retrieved from http://www.conecomm.com/2012corporatesocialreturntrendtracker

3. Cone Communications/Echo Global Corporate Responsibility Opportunity Study (2011). Retrieved from http://www.echoresearch.com/data/File/pdf/Cone_pdfs/2011

4. Cone Communications Holiday Trend Tracker (2012). Retrieved from http://www.conecomm.com/2012holidaytrendtracker

5. Cui, Y., E. S. Trent, P. M. Sullivan, and G. N. Matiru (2003), "Cause-Related Marketing: How Generation Y Responds," International Journal of Retail \& Distribution Management, 31 (6), 310-320.

6. DaSilva, A. (2004) "The 2004 Cone Corporate Citizenship Study," Boston: Cone Communications.

7. Eikenberry, Angela M. (2009), “The Hidden Costs of Cause Marketing," Stanford Social Innovation Review, 7 (3), 51-56.

8. Moosmayer, Dirk C. and Alexandre Fuljahn (2010), Journal of Consumer Marketing, 27 (6), 543-549.

9. Olsen, G. Douglas, John W. Pracejus, and Norman R. Brown (2003), "When Profit Equals Price: Consumer Confusion About Donation Amounts in Cause-Related Marketing," Journal of Public Policy \& Marketing, 22 (2), 170-180.

10. PRWeek/Barkley PR Cause Survey (2010). Retrieved from http://www.prweekus.com/causesurvey

11. Kim, Yeo Jung and Wei-Na Lee (2009), "Overcoming Consumer Skepticism in Cause-Related Marketing: The Effects of Corporate Social Responsibility and Donation Size Claim Objectivity", Journal of Promotion Management, 15 (4), 465.

12. Ross, John K., Larry Patterson, and Mary Ann Stutts (1992), "Consumer Perceptions of Organizations that Use Cause-Related Marketing,” Journal of the Academy of Marketing Science, 20 (1), 93-97.

13. Ross, John K., Mary Ann Stutts, and Larry Patterson (1990-91), "Tactical Considerations for the Effective Use of Cause-Related Marketing," Journal of Applied Business Research, 7 (2), 58-65.

14. Varadarajan, P. Rajan \& Anil Menon (1988), "Cause-Related Marketing: A Coalignment of Marketing Strategy and Corporate Philanthropy," Journal of Marketing, 52 (July) 58-74.

15. Youn, Seounmi and Hyuksoo Kim (2008), "Antecedents of Consumer Attitudes toward Cause-Related Marketing", Journal of Advertising Research, March, 123-137. 


\section{NOTES}

